\title{
Influence of Vitamin B2, Ascorbic Acid and Melatonin on Ovarian Activities, Reproductive Performance of Ewes during the Summer Season under Subtropical Conditions
}

\author{
El Shahat $\mathrm{KH}^{1}{ }^{*}$, Waheed $\mathrm{MM}^{1,2}$, Khalifa $\mathrm{TAA}^{3}$, Sallam $\mathrm{AA}^{4}$ and El \\ Saidy BE ${ }^{4}$ \\ ${ }^{1}$ Department of Theriogenology, Egypt \\ ${ }^{2}$ Department of Clinical Studies, Kingdom of Saudi Arabia \\ ${ }^{3}$ Veterinary Research Institute, Greece \\ ${ }^{4}$ Animal Production Research Institute, Egypt
}

Research Article

Volume 2 Issue 6

Received Date: December 03, 2019

Published Date: December 17, 2019

DOI: $10.23880 /$ izab-16000191

${ }^{*}$ Corresponding author: KH El Shahat, Department of Theriogenology, Faculty of Veterinary Medicine, Giza, 12211 Egypt, Tel: 0201064688386; Email: attiakh@yahoo.com

\section{Abstract}

The present study was conducted to investigate the effect of different treatments (vitamin B2, ascorbic acid and melatonin) on ewes' fertility rates during summer under the local environmental conditions. The study was carried out on 42 mature cross ewes (3/8 Finnish X 5/8 Rahamani). Ewes were allocated into 4 groups: the first group (G1; n=11) injected with $2 \mathrm{~mL}$ saline for 3 wk., served as control. The second (G2; n=10) and third group (G3; n=11) were injected intramuscular daily for $3 \mathrm{wk}$ with $2 \mathrm{~mL}(15 \mathrm{mg})$ of vitamin B2 and ascorbic acid, respectively. Ewes of the fourth group ( $G 4 ; n=10$ ) received twice daily subcutaneous injections of $0.5 \mathrm{mg}$ melatonin at 8AM and 4PM at the dorsal surface of the ear for 3 wk. All treated groups (G2, G3, and G4) received 1g zinc chloride and 2.5mg chromium (Merck Millipore, USA) in form of $6 \mathrm{ml}$ oral drench once per week for 3 weeks. All animals were checked for the onset of estrus 2 times daily using an intact ram and ewes were bred via natural mating using 3 rams. Laparoscopic examinations were carried out throughout the study for detection of ovulation rates. Results revealed that ascorbic acid resulted in a significantly $(\mathrm{P}<0.05)$ decreased mean interval (days) from treatment to estrus as compared with the control group $(15.73 \pm 1.83$ vs. $22.64 \pm 2.50$, respectively). A remarkable improvement in the lambing rate in G2, G3 and G4 treated groups than in the G1 (80.0, 90.9, and 90.0 vs. $72.7 \%$, respectively) was also observed. The ovulation rate was significantly $(\mathrm{P}<0.05)$ elevated in G4 than that in G2 and G1 (1.60 \pm 0.16 vs. $1.20 \pm 0.13$ and $1.14 \pm 0.00$, respectively). The follicular development did not 
vary among groups. In conclusion, vitamin B2, ascorbic acid and melatonin have a beneficial effect on the reproductive performance of ewes during summer under subtropical conditions.

Keywords: Ewes; Vitamin B2; Ascorbic acid; Melatonin

\section{Introduction}

Sheep and goats are considered as prolific species, despite the fact that most breeds of both species show annual reproductive cycles [1]. During each annual reproductive cycle, there is a season of low or absent (anestrous season) and a season of high (breeding season) reproductive activity. Seasonal reproductive patterns of sheep are dependent largely on latitude [2,3], breed and are influenced to a lesser extent by other factors such as strain, age and nutrition [4]. However, the molecular mechanisms through which nutrition is involved in the control of reproductive activity are not completely known [5]. The photoperiod and the annual environmental temperature cycle, are the main modulators of seasonal reproduction; whereas, in tropical regions, the annual reproductive cycle in sheep and goats is more likely regulated by annual rainfall and food availability. Ewes are typically anestrus in spring after lambing and lactating and remain so until late august or early September. Seasonal anestrus reduces reproductive efficiency and continues to hinder productivity [6,7]. Therefore, the present study was conducted to investigate the effect of different treatments (vitamin B2, ascorbic acid and melatonin) on ewes' fertility rates during summer under the local environmental conditions.

\section{Material and Methods}

This study was approved ethically by the Ministry of Agriculture, Arab Repuplic of Egypt.

Approval \# 2732/24/2017

\section{Animals and Ration}

The study was conducted at the experimental sheep station of in Sakha belonging to animal production research institute. The station is located in the north part of Nile Delta (latitude 30' 01" N; longitude 31'21" E). Twenty mature cross ewes(3/8 Finnish x 5/8 Rahamani) aged between 2 to 3 years old weighting $40 \mathrm{~kg}$ average body weight were used in the present work. All ewes were fed Egyptian clover (Trifolume alexandrium), besides the green maize (Darawa) and wheat straw as a source of roughage. The concentrate mixture was comprised of Yellow corn (30\%), wheat bran (29\%), Anti corticatted cotton seed meal (25\%), soya bean meal (6\%), Rice bran (4\%), Molasses (3\%), Limestone (2\%) and common salts $(1 \%)$ as illustrated in Table 1 . Diet was formulated to meet the nutrient requirements of NRC [8] for sheep. All eyes were healthy and clinically free of external and internal parasites. Animals were housed in semi open yards.

\section{Experimental Design}

Relaying on laproscopic examination and evaluation of blood progesterone as described by Restall, et al. [9], all animals were confirmed as acyclic (true anestrum). No corpora lutea were found on both ovaries by laparoscope. Ewes were randomly allocated into four groups: the first group (G1; $\mathrm{n}=11$ ) injected with $2 \mathrm{~mL}$ saline for $3 \mathrm{wk}$., served as control. The second (G2; $n=10)$ and the third group (G3; $n=11$ ) were injected intramuscular daily for 3 wk. with $2 \mathrm{~mL}(15 \mathrm{mg})$ of vitamin B2 and ascorbic acid dissolved in distilled water, respectively. Ewes in the fourth group (G4; $\mathrm{n}=10)$ received twice daily subcutaneous injections of $0.5 \mathrm{mg}$ melatonin dissolved in $20 \mathrm{ml}$ of a mixture $(4: 1 \mathrm{v} / \mathrm{v})$ of water and ethanol at 8AM and $4 \mathrm{PM}$ at the dorsal surface of the ear for $3 \mathrm{wk}$. All treated groups (G2, G3, and G4) received 1g zinc chloride and $2.5 \mathrm{mg}$ chromium (Merck Millipore, USA, Cat \#. 1088161000 and 1120970500 , respectively) in form of 6 $\mathrm{ml}$ oral drench once per week for $3 \mathrm{wk}$.

\section{Reproductive Performance}

All the experimental ewes were detected for the onset of estrus .Estrus was detected every day by visual observation between 0900-1200 and 1400-1700 h using intact ram. Ewes were considered to be in estrus when standing to be mounted. Ewes came in heat were naturally bred by a proven fertile ram. Fertility measures including estrus response, time interval between the treatment to onset of estrus, lambing rates, number of lambs, sex ratio (male/ female) and frequency of single, twin and triplet were recorded for each group. 


\section{International Journal of Zoology and Animal Biology}

\section{Laparoscopic Examination}

Follicular population, size and ovulation rates were determined by Laparoscopies of $7 \mathrm{~mm}$ diameter, previous infiltration with lidocaine $2 \%$ in the puncture site as previously reported by Kelly, et al. [10] Abdel Monem, et al. [11]. Laparoscopic examination was carried out pre and post-treatment (after 3 weeks post treatment). Ovarian follicles were counted and classified according to their diameter into small $(>2 \mathrm{~mm})$, medium $(2-4 \mathrm{~mm})$ and large follicles $(>4 \mathrm{~mm})$ as well as number of corpora lutea on both ovaries were recorded.

\section{Hormonal Assay}

Individual blood samples were collected prior to the beginning of the study (pretreatment or 0 blood samples); thereafter, blood samples were daily obtained till the end of the study period. Blood samples were allowed to clot and sera were separated by centrifugation at $3000 \mathrm{rpm}$ for 15 minutes. Sera were divided into aliquots and frozen at $-20^{\circ} \mathrm{C}$ until assayed for progesterone. Serum progesterone was measured by competitive ELISA according to Wisdom, et al. [12] using kits obtained from Dima, Germany.

\section{Statistical Analysis}

Data were expressed as mean \pm SEM .The data were analyzed statistically by ANOVA method and Duncan's test was used to detect differences among means using SPSS $₫$ Statistical Software (SPSS $₫ 11.01$ for Windows, 2001). Reproductive performance percentages were analyzed by the Chi-square test.

\section{Results}

\section{Effect on Incidence of Estrous Expression and Time Interval between the Treatment to Onset of Estrus}

Table 1 showed that the incidence of estrous expression among different treatments was statistically non-significant. Meanwhile, the time elapsed from treatment to $1^{\text {st }}$ estrus was shorter in G3 than that in the other groups. Although this elapsed time was nonsignificant, there was a tendency of increase in the lambing rate in G2, G3 and G4 on comparison to G1 (Table 1).

\begin{tabular}{|c|c|c|c|c|}
\hline \multirow{2}{*}{ Groups } & \multicolumn{4}{|c|}{ Reproductive traits } \\
\cline { 2 - 5 } & Number of ewes & Estrus response (\%) & Onset of estrus(days) & Lambing rate (\%) \\
\hline G1 (Control) & 11 & $11(100.0)^{\mathrm{b}}$ & $22.6 \pm 2.5^{\mathrm{a}}$ & $8(72.7)$ \\
\hline G2 (Vitamin B2) & 10 & $10(100.0)^{\mathrm{b}}$ & $19.5^{\mathrm{ab}} \pm 1.5$ & $8(80.9)$ \\
\hline G3 (Ascorbic acid) & 11 & 11.5 & $15.7 \pm 1.8^{\mathrm{b}}$ & $10(90.9)$ \\
\hline G4 (Melatonin) & 11 & 10 & $19.8^{\mathrm{ab}} \pm 1.4$ & $9(90.0)$ \\
\hline
\end{tabular}

Values within the same column with different superscripts $(a, b)$ are different $(p<0.05)$.

Table 1: Incidence of estrus (\%), onset of estrus (Mean \pm S.E) and lambing rate (\%) among different treatments.

\section{Effect on Lambing Rate Lambing Rates, Number of Lambs, Sex Ratio (Male/ Female) and Frequency Of Single, Twin And Triplet}

Table 2 declared that the mean number of lambs per ewe was not altered significantly among the different treatments. The higher percentage of ewes having one lamb was observed in G3 (100.00\%) and the lower one
(75.00\%) was recorded in G2. The proportion of twinning among different groups (G1, G2, and G4) was not varied. Incidence of lamb mortality (3 out of 11) was observed only in a vitamin B2 treated ewe bearing a triplet (Table 2). The sex ratio (male/female) was found to be higher in G4 than in the other groups.

\begin{tabular}{|c|c|c|c|c|c|c|c|c|}
\hline \multirow{2}{*}{ Groups } & \multirow{2}{*}{ No. of lambs born } & \multirow{2}{*}{ Litter size at Birth } & \multicolumn{2}{|c|}{ Sex of lamb } & \multicolumn{3}{|c|}{ No. of ewe bearing (\%) } \\
\cline { 4 - 8 } & & & $\mathbf{M}$ & $\mathbf{F}$ & $\mathbf{M} /$ F ratio & Single & Twin & Triplet \\
\hline G1 (Control) & 9 & $1.13 \pm 0.13$ & 4 & 5 & 0.8 & $7(87.5)$ & $1(12.5)$ & 0 \\
\hline G2 (Vitamin B2) & 11 & $1.38 \pm 0.26$ & 7 & 4 & 1.7 & $6(75.0)$ & $1(10.0)$ & $1(12.5)^{*}$ \\
\hline G3 (Ascorbic acid) & 10 & $1.00 \pm 0.00$ & 5 & 5 & 1 & $10(100)$ & 0 & 0 \\
\hline G4 (Melatonin) & 10 & $1.11 \pm 0.11$ & 8 & 2 & 4 & $8(88.8)$ & $1(11.1)$ & 0 \\
\hline
\end{tabular}

*The born lambs died

Table 2: Survey of born lamb between groups (Mean \pm S.E). 


\section{Effect on Follicular Population, Size and} Ovulation Rates

According to laparoscopic examination of ewes after 3 week post-treatment (Table 3), there was a significant $(\mathrm{P}<0.05)$ higher percentage of ovulated ewes in G1, G2 and G4 as compared to G3. On other hand, G4 ewes had a significant $(\mathrm{P}<0.05)$ increase in ovulation rate than those in G1 and G2 groups (Table 3). Table 4 showed that the follicular development was similar without any significant difference in ewes among different groups after 3 weeks post treatment.

\begin{tabular}{|c|c|c|c|c|c|c|}
\hline \multirow[b]{2}{*}{ Groups } & \multirow{2}{*}{ Number of examined ewe } & \multicolumn{4}{|c|}{ Sovulated ewes $1 \%$ Number of corpora lutea } & \multirow{2}{*}{$\begin{array}{c}\text { Ovulation rate (mean } \pm \\
\text { SEM) }\end{array}$} \\
\hline & & Svulated ewes $(\%)$ & Right & Left & Total & \\
\hline G1 (Control) & 9 & $7(100.0)^{a}$ & 4 & 4 & 8 & $1.14^{\mathrm{a}} \pm 0.00$ \\
\hline G2 (Vitamin B2) & 11 & $10(100.0)^{\mathrm{a}}$ & 5 & 7 & 12 & $1.20^{\mathrm{a}} \pm 0.13$ \\
\hline G3 (Ascorbic acid) & 10 & $4(66.6)^{b}$ & 5 & 2 & 7 & $1.75 \mathrm{ab} \pm 0.25$ \\
\hline G4 (Melatonin) & 10 & $10(100.0)^{\mathrm{a}}$ & 5 & 11 & 16 & $1.60^{b} \pm 0.16$ \\
\hline
\end{tabular}

Values with different superscript in the same column are significantly different at $\mathrm{P}<0.05$.

Table 3: Laparoscopy of ovarian activity in ewes three weeks post-treatment (Mean \pm S.E).

\begin{tabular}{|c|c|c|c|c|}
\hline \multirow{2}{*}{ Groups } & \multirow{2}{*}{$\begin{array}{c}\text { Number of } \\
\text { examined ewes }\end{array}$} & $\begin{array}{c}\text { Small follicles } \\
(<\mathbf{2 m m})\end{array}$ & $\begin{array}{c}\text { Medium follicles (2- } \\
\mathbf{4 m m})\end{array}$ & Large follicles (>4mm) \\
\hline G1 (Control) & 7 & $4.67 \pm 1.05$ & $1.33 \pm 0.61$ & $0.33 \pm 0.21$ \\
\hline G2 (Vitamin B2) & 10 & $4.71 \pm 1.21$ & $1.29 \pm 0.36$ & $0.57 \pm 0.30$ \\
\hline G3 (Ascorbic acid) & 6 & $2.83 \pm 0.98$ & $0.67 \pm 0.33$ & $0.50 \pm 0.34$ \\
\hline G4 (Melatonin) & 10 & $5.00 \pm 2.48$ & $0.50 \pm 0.29$ & $0.25 \pm 0.25$ \\
\hline
\end{tabular}

Values with different superscript in the same column are significantly different at $\mathrm{P}<0.05$.

Table 4: Ovarian follicular development in different groups (Mean \pm S.E).

\section{Effect on Serum Progesterone Concentration}

At the beginning of dietary supplementation, there were no significant differences between groups in the concentration of serum progesterone. The circulating serum progesterone was ranged from $0.36 \pm 0.41$ to $0.52 \pm$ $0.43 \mathrm{ng} / \mathrm{ml}$. Three weeks later, serum progesterone concentrations started to increase from day 15 in G3 and from day 20 in the other groups as shown in Table 5.

\begin{tabular}{|c|c|c|c|}
\hline \multicolumn{3}{|c|}{ weeks of study } \\
\hline Groups & 0 $^{\text {th }}$-week & $\mathbf{2}^{\text {nd }}-$ week & $\mathbf{3}^{\text {th }}$-week \\
\hline G1 (Control) & $0.36 \pm 0.41^{\text {a }}$ & $0.52 \pm 0.43^{\text {a }}$ & $1.5 \pm 0.43^{\text {a }}$ \\
\hline G2 (Vitamin B2) & $0.51 \pm 0.50^{\mathrm{a}}$ & $0.6 \pm 0.43^{\mathrm{a}}$ & $1.6 \pm 0.43^{\mathrm{a}}$ \\
\hline G3 (Ascorbic acid) & $0.52 \pm 0.33^{\mathrm{a}}$ & $1.5 \pm 0.17^{\mathrm{b}}$ & $25 \pm 0.17^{\mathrm{b}}$ \\
\hline G4 (Melatonin) & $0.42 \pm 0.40^{\mathrm{a}}$ & $0.6 \pm 0.43^{\mathrm{a}}$ & $1.6 \pm 0.43^{\mathrm{a}}$ \\
\hline
\end{tabular}

Means with different superscripts within the same row were significantly different at $\mathrm{p}<0.05$.

Table 5: Serum progesterone concentration $(\mathrm{ng} / \mathrm{ml})$ among different groups during the study (Mean \pm S.E).

\section{Discussion}

In the present study (under subtropical conditions), there was no difference between experimental and control group on the incidence of estrus. Similar findings were obtained by El-Maghraby, et al. [13] in mature Finn crossed ewes under subtropical conditions. However, the incidence of estrus was significantly improved in melatonin 120 implanted ewes for 40 days (75\%) compared to control ones (59\%) in United States of America (subtropical) as reported by Stellflug, et al. [14]. The obtained data revealed higher incidence of estrus $(100 \%)$ in untreated ewes (control group). In this respect, Aboul Naga, et al. [15] reported that about 33\% of Rahmani ewes showed continuous ovarian activity throughout the year, whilst almost all ewes had periods of behavioral anestrus under subtropical conditions. The mean interval from treatment to the onset of estrus 


\section{International Journal of Zoology and Animal Biology}

observed in the present study was significantly shorter for ewes received ascorbic acid than controls (15.73 \pm 1.83 vs. $22.64 \pm 2.50$ respectively). Ascorbic acid possesses many biological actions that are relevant with its role as a reducing agent; it is required for the biosynthesis of collagen which is essential for follicular growth and repair of the ovulated follicle [16], for corpus luteum development [17], for biosynthesis of steroid and peptide hormones, and to prevent or reduce the oxidation of biomolecules [18]. In the current study, there was a non-significant effect of vitamin B2, ascorbic acid and melatonin on the lambing rates. However, exogenous vitamin $\mathrm{C}$ application prevents oxidative stress and increases the fertility rate along with body weight of pregnant ewes and newborns in Turkey (temperate; injected intramuscular; [19] and Chile (subtropical; administrated orally during mating and gestation period [20]. Moreover, vitamin C supplementation is essential for water-stress alleviation in sheep under subtropical conditions [21]. In addition, the reported lambing rate in the melatonin treated group $(90.00 \%)$ is close to that recorded (88.89\%) in Egypt (subtropical) by ElMaghraby, et al. [13]. Furthermore, in Spain (temperate), Abecia, et al. [22] observed that melatonin intravenous treatment in sheep can increase both fertility and prolificacy by improving luteal function. The beneficial effect of vitamin B2 on reproductive performance of ewes observed in the present study was similar to that described early in cattle by Hurley, et al. [23] who found that all B-vitamins are required for the growth and development of fetus. In this study, ascorbic acid and melatonin had almost no effect on the occurrence of triplet fetuses. This is a desirable outcome in ewes with low fecundity under local conditions where mortality of triplet bearing ewes is very high. The same conclusions were obtained by William, et al. [24] in Merino ewes in Australia (temperate) by using melatonin subcutaneous implants. On the contrary, DeNicolo, et al. [25] reported that melatonin subcutaneous implants in conjunction with administration of progesterone and equine chorionic gonadotrophin increased the number of lambs born per ewe treated in an out-of-season breeding program in New Zealand (temperate country) sheep flocks. As shown in the present study, the sex ratio $(\delta / P)$ in G4 (4.00) was higher than in G1, G2 and G3. However, there was no significant difference between melatonin and control groups (1.063 vs. 1.026, respectively) as also cited by Williams, et al. [24]. In this study, the ovulation rate was significantly $(\mathrm{P}<0.05)$ improved in G4 than in G2 and G1 groups. These results are in accordance with the findings of Forcada, et al. [26] in Spain (temperate) in sheep during the anestrous periods. Melatonin may regulate cyclic activity in ewes by affecting the hypothalamohypophesial axis [27]. It plays a key role in the transfer of photoperiodic information to the neuro-endocrine axis [28]. Furthermore, Song, et al. [29] recorded that, melatonin at $5 \mathrm{mg}$ subcutaneously injected into the neck during estrus would increase the level of melatonin and estradiol in the blood of ewe, and melatonin promoted embryo production and the pregnancy rate in the ewes naturally mated or embryo transfer. In addition, melatonin administration improved the conception rates in mice and cows [30]. Also, melatonin added during culture of mouse prokaryotic embryos significantly increased blastocyst rate, pregnancy rate after transplantation, average number of offspring and survival rate of offspring [31]. For deer, melatonin subcutaneous implantation also improved the quantity and quality of super ovulatory oocytes [32]. In the present work, follicular activity as indicated by the presence of medium and large sized follicles was observed in ewes of different groups without any significant difference. The same finding was reported by Wheaton, et al. [32] in Suffolk ewes fed $3 \mathrm{mg}$ melatonin daily for 44 days in United States of America (subtropical). In the current study, serum progesterone levels started to increase between days 15 and 20 after treatment in all groups. These observations are consistent with previous studies which indicate that melatonin treatment increases serum LH and progesterone levels in goat and deer [34,35]. This increase in progesterone recorded herin indicated the cyclic activity in ewes. The serum progesterone concentration started to increase five days earlier in G3 (ascorbic acid treated) than the other groups. Vitamin C is believed to act as an antioxidant, neutralizing the oxidative by-products of cellular respiration in luteal cells, as an enzymatic cofactor in collagen synthesis and as a promotor of steroid and protein hormone synthesis $[19,36]$; However, no significant correlation between plasma vitamin $\mathrm{C}$ and progesterone levels was described in some studies [37,38]. In conclusion, vitamin B2, ascorbic acid and melatonin have a beneficial effect on the reproductive performance of ewes during summer under subtropical conditions [39-44].

\section{Conflict of Interest Statement}

We declare that we have no conflict of interest.

\section{References}

1. Jainudeen MR, Wahid H, Hafez ESE (2000) Sheep and goats. In: Reproduction in farm animals. $7^{\text {th }}$ (Edn.), 


\section{International Journal of Zoology and Animal Biology}

ESE Hafez, B Hafez, et al. (Eds.), Wiley-Blackwell, Iowa, USA pp: 172-181.

2. Chemineau P, Malpaux B, Delgadillo JA, Guérin Y, Ravault JP, et al. (1992) Control of sheep and goat reproduction: Use of light and melatonin. Anim Reprod Sci 30(1-3): 157-184.

3. Malpaux B, Viguie C, Skinner DC, Thiéry JC, Pelletier J, et al. (1996) Seasonal breeding in sheep: Mechanism of action of melatonin. Anim Reprod Sci 42(1-4): 109117.

4. Hafez ESE (1952) Studies on the breeding season and reproduction of the ewe Part III. The breeding season and artificial light Part IV. Studies on the reproduction of the ewe Part V. Mating behaviour and pregnancy diagnosis. J Agri Sci 42(3): 232-265.

5. Yang H, Lin S, Lei X, Yuan C, Yu Y, Zhao Z, et al. (2018) Nutritional status affects the microRNA profile of the hypothalamus of female sheep. Reprod Fertil Dev 30(7): 946-957.

6. Gündoğan M, Baki D, Yeni, D (2003) Reproductive seasonality in sheep. Acta Agriculturae Scandinavica, Section A-Animal Science 53: 175-179.

7. Porras A, Zarco LA, Valencia J (2003) Estacionalidad reproductiva en ovejas. Ciencia Veterinaria 9: 1-34.

8. NRC (1985) Nutrient requirement of sheep. $7^{\text {th }}$ (Edn.), Salamon, National Academy Press, Washington DC, USA.

9. Restall BJ, Restall H, Walkden Brown SW (1995) The induction of ovulation in anovulatory goats by estrous females. Anim Reprod Sci 40(4): 209-303.

10. Kelly RW, Allison AJ (1976) Measurement of ovulation rates by laparoscopy and effects on reproductive performance. Proc NZ Soc Anim Prod 36: $240-246$.

11. Abdel Monem UM, El Shahat KH (2011) Effect of different dietary levels of inorganic zinc oxide on ovarian activities, reproductive performance of Egyptian Baladi ewes and growth of their lambs. Bulg J Vet Med 14(2): 116-123.

12. Wisdom GB (1976) Cited in the insert of progesterone kit of Dima. Clin Chem 22: 1243.

13. El Maghraby MMIH (2003) Inducing oestrus and ovarian activity in ewes during anestrous period..
Master of Agriculture Science (Animal Production) Thesis, Tanta.

14. Stellflug JN, Fitzgerald JA, Parker CF, Bolt D (1988) Influence of concentration,duration and route of administration of melatonin on reproductive performance of spring-mated polypay cross ewes. J Anim Sci 66(8): 1855-1863.

15. Aboul Naga AM, Aboul Ela MB, El Nakhla SM, Mehrez AZ (1987) Oestrous and 190 ovarian activity of subtropical fat-tailed Rahmani sheep and their response to light 191 treatment. J Agri Sci 108: 617621.

16. Himeno N, Kawamura N, Okamura H, Mori T, Fukomoto M, et al. (1984) Collagen synthetic activity in rabbit ovary during ovulation and its blockage by indomethacin. Acta Obstet Gynaecol Jpn 36(10): 1930-1934.

17. Luck MR, Zhao Y (1993) Identification and measurement of collagen in the bovine corpus luteum and its relationship with ascorbic acid and tissue development. J Reprod Fertil 99(2): 647-652.

18. Sebrell WH, Harris RS (1967) The vitamins, chemistry, physiology, pathology and methods. New York Academic Press 1: 305-320.

19. Haliloglu S, Serpek B, Baspinar N, Erdem H, Bulut Z (2002) Relationships between plasma and ovarian vitamin $\mathrm{C}$, progesterone and $17 \beta$-estradiol levels of Holstein drunk pregnant cows. Tr J Vet Anim Sci 26: 639-644.

20. Parraguez VH, Atlagich M, Araneda O, García C, Muñoz A, et al. (2011) Effects of antioxidant vitamins on newborn and placental traits in gestations at high altitude: comparative study in high and low altitude native sheep. Reprod Fertil Dev 23(2): 285-296.

21. Ghanem AM, Jaber LS, Abi Said M, Barbour EK, Hamadeh SK (2008) Physiological and chemical responses in water-deprived Awassi ewes treated with vitamin C. J Arid Environ 72(3): 141-149.

22. Abecia JA, Forcada F, Zuniga O (2002) The effect of melatonin on the secretion of progesterone in sheep and on the development of ovine embryos in vitro. Vet Res Commun 26(2): 151-158.

23. Hurley WL, Doane RM (1989) Recent developments in the roles of vitamins and minerals in reproduction. J Dairy Sci 72(3): 784-804. 


\section{International Journal of Zoology and Animal Biology}

24. Williams AH, Mcphee SR, Reeve JL, Staples LD (1992) Optimum use of subcutaneous melatonin implants to enhance the reproductive performance of seasonal and non-seasonal sheep joined in spring and early summer. Anim Reprod Sci 30(1-3): 225-258.

25. DeNicolo G, Morris ST, Kenyon PR, Morel PC, Parkinson TJ (2008) Melatonin- duration and route of administration of melatonin on reproductive performance of spring-mated polypay cross ewes. J Anim Sci 66: 1855-1863.

26. Forcada F, Zarazaga L, Abecia J (1995) Effect of exogenous melatonin and plane of nutrition after weaning on oestrus activity endocrine status and ovulation rate in salz ewes lambing in the seasonal anestrus. Theriogenology 43(7): 1179-1193.

27. Arendt J, Laud CA, Symons AM, Pryde SJ (1983) Melatonin can induce early onset of the breeding season in ewe. J Endocrinol 97(3): 395-400.

28. David JK, Helmut MH (1992) Mechanism of action of melatonin within the central nervous system. Anim Reprod Sci 30(1-3): 45-65.

29. Song $Y$, Wu H, Wang X, Haire A, Zhang X, et al. (2019) Melatonin improves the efficiency of super-ovulation and timed artificial insemination in sheep. Peer J 7: 6750 .

30. Guo XH, Li YH, Zhao YS, Zhai YZ, Zhang LC (2017) Antiaging effects of melatonin on the myocardial mitochondria of rats and associated mechanisms. Molecular Medicine Reports 15(1): 403-410.

31. Yang, M, Shi J, Tian J, Tao J, Chai M, et al. (2017) Exogenous melatonin reduces somatic cell count of milk in Holstein cows. Scientific Reports 7: 43280.

32. He C, Ma T, Shi J, Zhang Z, Wang J, et al. (2016) Melatonin and its receptor MT1 are involved in the downstream reaction to luteinizing hormone and participate in the regulation of luteinization in different species. Journal of Pineal Research 61(3): 279- 290.

33. Wheaton JE, Pohl HA, Windels HF (1990) Effects of melatonin and progesterone administered to ewes in spring and summer. J Anim Sci 68: 923-930.

34. Zarazaga LA, Gatica MC, Celi I, Guzmán JL, Malpaux B (2009) Effect of melatonin implants on sexual activity in Mediterranean goat females without separation from males. Theriogenology 72(7): 910-918.

35. Wang L, Zhuo ZY, Shi WQ, Tan DX, Gao C, et al. (2014) Melatonin promotes superovulation in sika deer (Cervus nippon). Int J Mol Sci 15(7): 12107-12118.

36. Miszkiel G, Skarzynski D, Bogacki M, Kotwica J (1999) Concentrations of catecholamines, ascorbic acid, progesterone and oxytocin in the corpora lutea of cyclic and pregnant cattle. Reprod Nutr Dev 39(4): 509-516.

37. Serpek B, Baspmnar N, Halmloglu S, Erdem H (2001) The relationship between ascorbic acid, oestradiol $17 \beta$ and progesterone in plasma and in ovaries during the sexual cycle in cattle. Revue Méd Vét 152: 253-260.

38. Ymldmz H, Kaygusuzoğlu E, Kmzml Ö (2005) Serum progesterone, vitamin $\mathrm{A}, \mathrm{E}, \mathrm{C}$ and $\beta$-carotene levels in pregnant and nonpregnant cows post-mating. J Anim Vet Adv 4: 381-384.

39. David JK, Helmut MH (1992) Mechanism of action of melatonin within the central nervous system. Anim Reprod Sci 30: 45-65.

40. DeNicolo G, Morris ST, Kenyon PR, Morel PC, Parkinson TJ (2008) improved reproductive performance in sheep bred out of season. Anim Reprod Sci 124: 124-133.

41. Haliloglu S, Serpek B (2000) The effects of plasma vitamin $C$ supplementation on reproduction in sheep. Turk J Vet Anim Sci 24(4): 403-411.

42. Hashem NM, El Zarkouny SZ, Taha TA, Abo Elezz ZR (2011) Effect of season, month of parturition and lactation on estrus behavior and ovarian activity in Barki x Rahmani crossbred ewes under subtropical conditions. Theriogenology 75(7): 1327- 1335.

43. Aboul Naga AM, AboulEla MB, El Nakhla SM, Mehrez AZ (1987) Ovarian activity of subtropical fat-tailed Rahmani sheep and their response to light treatment. J Agri Sci 108(3): 617-621.

44. SPSS (2001) Statistical package for the social sciences. 